\title{
Theorizing the Religious Habitus in the Context of Conversion to Islam among Polish Women of Catholic Background
}

\author{
Joanna Krotofil ${ }^{*, \bullet}$ \\ Jagiellonian University \\ Anna Piela ${ }^{\circ}$ \\ Northwestern University \\ Katarzyna Górak-Sosnowska \\ SGH Warsaw School of Economics \\ Beata Abdallah-Krzepkowska \\ University of Silesia in Katowice
}

This article explores the conversion processes of Polish women of Catholic background to Islam. Data from participant observation of mosque-based, women-only weekend gatherings for converts and in-depth interviews with 29 Polish female converts to Islam are presented to illustrate the dialectic between the persistence and transformation of religious habitus. Our analysis demonstrates that in the conversion process, Catholic habitus remains pervasive, and shapes converts' engagement with the new religion; however, some elements of it become reflexive and change. We make a case for extending the discussion on habitus transformation by drawing attention to what we term a "translation" of religious beliefs and practices. Women in our study translate the system of Islamic practices and beliefs into a specific Catholic logic that is more intelligible to them and, in the process, recognize some of the power dynamics inherent in the religious field.

Key words: Islam; habitus; translation; conversion; Catholicism; Poland.

In the contemporary world of heterogeneous identities, individual habitus is unlikely to be tied to a single religious or cultural tradition. Social identities are fashioned out of a whole range of often-contradictory experiences. Habitus produced at the intersection of multiple social fields is no different and often

*Direct correspondence to Joanna Krotofil, Jagiellonian University, ul Grodzka 52, 31-044, Kraków, Poland. E-mail: Joanna.krotofil@uj.edu.pl.

(C) The Author(s) 2021. Published by Oxford University Press on behalf of the Association for the Sociology of Religion.

This is an Open Access article distributed under the terms of the Creative Commons AttributionNonCommercial-NoDerivs licence (https://creativecommons.org/licenses/by-nc-nd/4.0/), which permits non-commercial reproduction and distribution of the work, in any medium, provided the original work is not altered or transformed in any way, and that the work is properly cited. For commercial re-use, please contact journals.permissions@oup.com 
consists of conflicting elements. We argue, however, that a particular religious habitus may be shared by individuals with a common religious upbringing and remain salient also among those who convert to a different religion in later life. In this article, we explore the conversion processes of Polish women of Catholic background who have embraced Islam in the last three decades. We focus on the dialectic between the persistence and transformation of their religious habitus and explore how the hegemony of the Catholic Church in Poland is reflected in the set of embodied dispositions which can be termed a "Catholic habitus" (Inglis 2004; Shanneik 2011). In our analysis, we draw on Bourdieu's original work and the work of his commentators in order to apply his concept of habitus to the empirical data on conversion to Islam generated in our study in a way that best illuminates the data and facilitates better understanding of converts' experiences. Focusing on the religious practices of female converts to Islam, we foreground the concept of habitus at the expense of other key concepts in Bourdieu's theory of practice-capital and field. Thus, we use habitus as an analytical tool, to some degree "open and provisional" (Bourdieu 1990a:40). Through careful analysis of the conversion process, we wish to contribute to the theoretical debate on the conditions and mechanisms of habitus transformation. We make a case for extending the scholarly discussion on habitus transformation by drawing attention to what we term a "translation" of Islamic religious beliefs and practices into Catholic ones. We demonstrate the presence of this action within converts' narratives, and how it is used in the process of habitus adjustment when a mismatch between individuals' dispositions and structure of the field is experienced.

\section{BACKGROUND LITERATURE}

\section{Religious Habitus}

In Bourdieu's work, habitus is a concept used to build a disposition-based theory of practice. Social actors produce meaning and structure the world through practice; this process is shaped by the habitus — embodied schemas constituted by the objective conditions and inculcated in the individual during socialization (Bourdieu 1990b). Elsewhere, Bourdieu defines habitus as "a subjective but not individual system of internalized structures, schemes of perception, conception, and action common to all members of the same group or class" (1977:86). This set of embodied dispositions produces the common-sense world, makes practices "taken for granted," and instills things with cultural values (Bourdieu 1977:81). It is a deeply internalized "system of structured, structuring dispositions" (Bourdieu 1990b:52), and as it is recreated in new contexts, it reproduces the structures of which it is a product and makes us recognizable to ourselves. The habitus in Bourdieu's theory is closely related to the concept of field, "a structured place of social forces and struggle" (Bourdieu and Wacquant 1992:243). There is an 
"ontological correspondence" between habitus and field: the fields shape the habitus, and the habitus, in turn, renders the field "meaningful" (Rey 2007:46).

Bourdieu's work on habitus is highly debated and criticized. Probably the most consistent criticism pertains to the growing discontinuity of contemporary biographies and the usefulness of the habitus in studying individuals engaging with rapidly changing social realities (Archer 2012; Decoteau 2016; Mellor and Shelling 2014). One of the main concerns is the supposed determinism inherent in Bourdieu's conceptualization of habitus precluding any challenge to the status quo (Bouzanis and Kemp 2019; Jenkins 1982; King 2000; Trzebiatowska 2014). Bourdieu himself allows for habitus change, although he gives more weight to the stability over time and highlights hysteresis- the lag occurring in the change of habitus unadjusted to the new logic and structure of the field (Wacquant 2004:392). For Bourdieu, the habitus "ensures the active presence of past experiences, which [...] tend to guarantee the 'correctness' of practices and their constancy over time, more reliably than all formal rules and explicit norms" (1990b:54). It could be argued, however, that while such a take on the change and stability provides a satisfying solution to the problems inherent in the conceptualizations of individual action governed by explicit rules, it prompts another question about how the habitus can be reconciled with the explicit norms that have changed.

Another related criticism pertains to the postulated passive acquisition of habitus and the way it operates beyond introspection or conscious control (Bourdieu 1984). It has been argued that such a conceptualization of habitus is irreconcilable with individual agency (Archer 2012). Some commentators, however, note that the criticism stems from some inconsistencies, or fluctuations of emphasis in Bourdieu's writing (Bouzanis and Kemp 2019; Crossley 2001; Decoteau 2016; Hilgers 2009; King 2000; Noble and Watkins 2003). In his late writings, Bourdieu explicitly acknowledges the possibility of "'self-work' that enables the individual to get a handle on his or her dispositions" (Bourdieu and Wacquant 1992:133).

In the following sections, we argue that Bourdieu's habitus can be reconciled with reflexivity, individual agency, and change, and conceptualized as a set of relatively stable dispositions that nevertheless undergo transformation. In the extensive literature on habitus, scholars have offered numerous arguments against ruling reflexivity out of habitus (Adams 2006; Sweetman 2003). Bourdieu notes that "consciousness and reflexivity are both cause and symptom of the failure of immediate adaptation to the situation" (Bourdieu 1990a:11) and, therefore, suggests that reflexivity occurs in dramatic conditions of crisis. Rejecting the crisis as the necessary condition for the reflexive modification of individual dispositions, Crossley (2001) argues that habitus change can be the effect of communicative engagement between well-adapted agents, an assertion corroborated by many narratives collected in our study. 
Bourdieu (2001:32) notes that the dispositions are the product of embodiment of the views "instituted in the order of things" and, therefore, the transformation of disposition and the development of new ones have to be placed within the familiar "order of things." We demonstrate this with reference to religious habitus of individuals who come into contact with a new religious milieu and propose that making connections between the old and new religions through translation of religious beliefs, practices, and institutions is of key importance in the process of conversion. We define translation as a reflexive process of interpretation performed in a search for some correspondence or equivalence between beliefs, practices, or institutions of the two religions. In the course of translation, selected elements of the respective religions are perceived as comparable and some similarities between them are identified. The process might involve abstraction from a cultural context, or the opposite operation-assigning specific meaning to a new belief, practice, or institution by placing it in a socio-cultural context-in order to link it with a belief, practice, or institution known from the heritage religion. The translation process allows for simultaneous explaining and defending of beliefs and practices (Asad 1986). The process involves individualization of religion, as translation is not legitimized by religious institutions and operates on the basis of the logic of the translator's subjectivity.

Rey (2007:93) notes that religious habitus influences how a social actor "perceives of, responds to, and uses religious symbols and/or engages in rituals," how he or she reacts "to religious leaders," "what forms of religious capital she or he deems worthy of pursuit, and generally on how she or he fares in the religious field." Previous research on conversion to Islam suggests that religious habitus developed prior to conversion is recreated and shapes converts' experiences (Roy 2004; Shanneik 2011). Data collected in our research corroborate these findings. We argue that during and after the conversion, the habitus formed by the heritage religion remains pervasive and continues to influence the way the new religion is learned and embodied. For new Muslims, it provides the framework for comprehending Islamic practice, and certain embodied dispositions, enabling them to engage in religious practices.

In studying contemporary religious life, failure to engage with individual agency limits our understanding of how religious identities emerge in contexts of increasing religious pluralism. In this paper, we present a study on conversion to Islam, a process that is inherently linked with the social and cultural complexity of the contemporary world, where migration, social mobility, and rapid expansion of technologically mediated circulation of information are the very conditions that render possible the encounter of Polish women with Islam. In line with this, we reject the notion of habitus as an unchangeable disposition developed from routinized practices. Instead, we explore the empirical validity of the re-conceptualized understanding of religious habitus as embodied cultivation 
of religious knowledge, symbols, and practices that can be reflexive (Decoteau 2016; Mellor and Shilling 2014). ${ }^{1}$ This perspective highlights the creative potential of interaction between an individual and religious tradition, where "religious traditions both shape and are shaped by the internal conversations of individuals and the reflexive development and management of embodied dispositions and orientations" (Mellor and Shelling 2014:282).

The point of departure for our analysis is the reflexivity of habitus that manifests itself in making connections between Catholic and Islamic religious ideas, symbols, and practices. Converts connect the two religions by comparing and translating. We argue that, as it is not possible "to live the belief" associated with profoundly different conditions of existence (Bourdieu 1990b:68), the belief must be translated to match the individual's reality. In line with Bourdieu's criticism of the objectification of experiences of those who are the subject of anthropological research (Bourdieu 1990b), we assert that the translation is not a purely discursive endeavor. For the author, "Practical belief is not a 'state of mind', still less a kind of arbitrary adherence to a set of instituted dogmas and doctrines ('beliefs'), but rather a state of the body" (Bourdieu, 1990b:68), and thus, the translation of religious practices and beliefs concerns the body and mind.

As a locus of lived religion, the body-especially the gendered and sexual body - is not only the marker of piety, but also a means to its achievement (Mahmood 2005; Mossiere 2011; Rao 2015; Winchester 2008). Of particular importance in the context of conversion and learning new religious practices is the "stubbornness" of human bodies, which allows for change, but puts limits to it (Mellor and Shilling 1997:18). Bourdieu opposes the notion that habitus is acquired through mechanical learning through trial and error, but at the same time rejects the cognitive, or representational position, by highlighting that bodily schemes can pass from practice to practice "without moving through discourse and consciousness" (1990b:74). However, as has been convincingly argued in sports research, deconstructive and synthetic reflections are crucial to the acquisition and refinement of embodied techniques (Noble and Watkins 2003). While Bourdieu notes that the state of the body gives rise to the state of the mind, by connecting the embodiment of new religious practice with the notion of translation, we argue that this relationship works in both directions.

${ }^{1}$ An alternative conceptualization of habitus explored in studies of contemporary Islam is the notion of habitus as a moral disposition used by Mahmood (2005) and Asad (1993). Their work has also faced criticism regarding an inadequate conceptualization of agency. These authors assume actions to be products of tradition and authoritative discourses. In this framework, subjects are not capable of consciously acting on their own behalf but are produced and organized by systems of power exceeding their conscious control (Mellor and Shilling 2014; Winchester 2008). 


\section{Polish Catholic Habitus}

In the discussion of religious habitus, Catholics are evoked as an example of a collective participating in "the same religious collusion" and sharing religious habitus formed by "a very centralized and unifying liturgical spine" (Rey 2007:88). The manner in which Polish converts engage with new religious practices and beliefs cannot be separated from the beliefs and practices of the Catholic Church. Following the collapse of state socialism, the hegemonic position of the Catholic Church in Poland has been reinforced in the last few decades, and has led to a widespread conflation of Catholicism, patriotic virtue, and morality (Mach 2007; Mishtal 2015). While the estimated total number of Muslims in Poland is somewhere between 25,000 and 35,000 (Račius 2018), accounting for less than $0.1 \%$ of the population, Catholicism remains the dominant religious affiliation. It is considered to be a mainstream religious identity and foundational for the construction of the national Polish identity (Topidi 2019). ${ }^{2}$ Many elements of Catholic religious practice, including baptism of children, confirmation, and having a religious wedding ceremony, are so normalized in modern-day Poland that they are observed even by those Poles who self-define as non-believers but are in fear of social ostracism directed at them or their children (Tyrała 2018). The deep penetration of Catholic doctrine has undoubtedly been bolstered by the signing of the 1993 Concordat with the Holy See, which has paved the way for Catholic instruction in Polish public schools. Although formally defined as an elective course, attendance has become socially and institutionally normative (Topidi 2019).

The naturalized and internalized experiences, practices, ideologies, and perceptions learned during childhood and early adult years continue to manifest themselves in the navigation of the religious field after conversion. What parallels the embracement of the new religion is the reflexive bringing together of different ideas, practices, and institutions by comparing, retaining, reinterpreting, or rejecting some of those associated with the previous religious orientation and learning and incorporating new ones.

\section{RESEARCH SETTING AND METHODS}

Our findings are based on analysis of data collected from a group of Polish women converts to Islam. The data include notes from participant observation conducted during three mosque-based, women-only weekend gatherings organized for Polish converts in Warsaw, and individual in-depth interviews conducted between 2019 and 2020 with 29 Polish women who converted to Islam. The interview data were collected in the locations chosen by our respondents-usually

${ }^{2}$ In the religious field structured in this way, Islam in Poland occupies a relational position of "the Other" par excellence; it is often portrayed as backward and violent and placed in a stark opposition to "Polish values" (Krotofil and Motak 2018; Piela 2020). 
in their homes, or in public spaces, such as cafes, or parks. The interviews were semi-structured and followed a topic guide focused on participants' experiences of coming to Islam.

Participants were aged 24-60 and included both recent converts as well as women who had embraced Islam in the early 1990s. They lived in different regions of the country; two self-identified as Silesians (members of an ethnic minority in Poland) rather than Poles. Some were very active in Muslim organizations and associations, while others were active in informal convert groups. As noted elsewhere (Krotofil et al. forthcoming), while we attempted to achieve diversity in terms of education, class background, age, marital/parental status, and Islamic affiliation, we recognize that some categories, for example rural women, are less represented in our sample. ${ }^{3}$

The sample reflects the diversity of lived experiences of Islam in Poland. While most commonly the women did not identify with any particular school of Islam, some of our participants recognized their affinity with Salafi ideas and aspired to embody the traditional model of piety and devotion by relying on literal readings of Quranic texts and the Sunna. Another significant group of participants identified with more liberal and flexible interpretations of Islam, actively incorporating considerations of time and place in their perspective. Some women in this latter group self-identified as feminist, and/or leftist. Finally, a significant proportion of our participants highlighted the spiritual aspects of Islam, sometimes inspired by Sufi movement and characterized by a degree of religious individualization. As the sample is purposive, we do not make claims regarding the representativeness of our findings.

In recruitment, we initially relied on our existing research networks; all researchers were Polish women with experience of previous work with Muslim communities in Poland and the UK. Importantly, one researcher is herself a convert to Islam, which positioned her as a "peer" researcher, offering unique access opportunities to the project (Ryan, Kofman, and Aaron 2011). The participants signed an informed consent form, and they were randomly assigned pseudonyms to protect their anonymity.

${ }^{3}$ The sample comprises White women only. Poland is one of the Europe's most racially homogeneous societies, although no official statistics related to race are officially maintained in Poland (Balogun 2020). Race is not a salient category in Polish national narratives, as Whiteness is largely naturalized and nested within the larger Polish identity; it is thus made invisible. Crucially, racism emerged hand-in-hand with the processes of identifying racialized Others-Jews, Roma, Muslims, and persons of African heritage-within the Polish polity (Balogun and Joseph-Salisbury 2021). White Polish women who convert to Islam and adopt the hijab (both in Poland and the UK) become "non-normatively" White (Galonnier 2015) and, by extension, "non-normatively" Polish. Upon the adoption of the niqab (the face veil, worn by two respondents), their Whiteness, and any associated social and cultural capital, are "confiscated" (Moosavi 2015:45). Niqab-wearing women are constructed as non-White altogether. In the converts' narratives, negative reactions to their Muslim identity are, however, framed almost exclusively by references to Islamophobia, rather than racism. 


\section{FINDINGS}

\section{Membership in a Convert Community Characterized by a Shared Catholic Background}

Becoming a Muslim is, first and foremost, a social process and takes place predominantly in a field that is already structured, but also subject to constant transformation: the community of Polish converts who have in common their Catholic background. All of our respondents are, at the very least, familiar with rudimentary Catholic beliefs and practices. However, just as they form a diverse group with respect to their conversion motivations and the ways they "do Islam," their relationship with Catholicism is also far from homogeneous. When relating their religious beliefs and practices from the period prior to conversion, most of the women described themselves as having been raised in Catholic families and actively involved in the Catholic Church; many among them formerly belonged to lay Catholic groups and movements. This kind of relationship would place them in a category of "strong" Catholics proposed by Tom Inglis (2004). ${ }^{4}$ Others could be described as "cultural" or "creative" Catholics at some point of their life. Finally, for a small minority of our participants, their involvement with Catholicism before conversion would be categorized as "alienated" Catholics in Inglis's typology.

Several women we interviewed described a period in their lives when they questioned some elements of Catholicism:

My parents are Catholics, they have always been believers, they still are. I always had [holy] images at home... We always invited the priest to our house, we had friends who were nuns. This is not me rejecting this. But I always wondered why I had to pray at church? Why can't I pray anywhere? All my life, since I can remember, I asked the Catholic educators, I joined Oaza [a lay revivalist Catholic movement founded in Poland], I asked the priest about stuff. (Kamila)

For some, the religious quest started with the rejection of some of the Catholic teachings. "I knew there was a God...that God was in our lives, that God helped us, but I didn't really need religion," stated Julia. Similarly, Ula asserted: "my parents are very active in the Catholic Church, my dad is a lector. My brothers were altar boys. But as part of my teenage rebellion, at 15, I started my quest, I learned about other religions and became interested in them."

${ }^{4}$ Inglis (2004) proposes four types of identification with the institutional Church. Strong Catholics accept most teachings of the Church, regularly engage in Church rituals, and are actively involved in the life of the Church. Cultural Catholics attend Church ritual sporadically and they are more detached from the Church, but Catholicism remains an important part of their national identity and family heritage. Creative Catholics choose which practices, teachings, and rules they adhere to, and sometimes mix them with non-Catholic practices. Finally, alienated Catholics are detached from the Church and religious life, but still see themselves as Catholics. 
After learning about other religions, Ula eventually chose Islam. Perhaps it could be argued that there is an elective affinity (Clough 2006; Weber 1992) between Catholicism and the forms of Islam embraced by Polish converts. The categories of perception derived and reinforced by the respective belief systems are broadly similar, and as we will demonstrate later, they are often compared and linked by the participants. The religious practices in Islam and Catholicism also share many qualities on a general level. Polish women raised in the society infused by Catholicism are familiar with membership in a ritual community and the idea of collective prayer. They know and anticipate changes of body alignment during prayer and associate these postures with humility, and many have the experiences of fasting and pilgrimage (Clough 2006). The new system of dispositions developed by those who embrace Islam through interactions with other converts gradually endows individuals with the capacity to intuit what constitutes suitable behavior in each situation, "for the likes of us" (Bourdieu 1990b:56), in this case, for Polish female converts to Islam. In the process of becoming Muslims, converts reflexively position themselves not only in relation to non-Muslim women (Rao 2015), but also in relation to other Muslims, as illustrated by the following quote:

Well, for me, being a Muslim is not enough. I don't just want to be a Muslim, I want to be a believing Muslim, the best Muslim I can be. I want to give, compete with other Muslim women, not in a bad sense, but rather so that I do not have to follow other Muslim women, and have them to follow me. I want to reach a point when I develop to the best of my ability. (Beata)

The new religious practice is, therefore, by no means generic: the meaning assigned to it is connected to the collectively shared, localized understandings of Islam shaped by the Catholic habitus. As Crossley observes, "[...] the individual belongs to a group or variety of groups and develops his or her habits therein. Thus, the individual habitus tends to manifest many group-specific characteristics" (2001:84). Although tracing the objective analogies between pre-and post-conversion practice and comparing converts' practices and beliefs with those of women who are Muslims from birth is beyond the scope of our study, the observations and narratives collected in our project indicate that for the first group, being a Muslim is palpably inflected with either Catholic practices or theology.

\section{Translating Religious Beliefs}

The process of learning new beliefs and religious practices is very complex, and women who participated in our study utilized many tools to facilitate the fit between their dispositions and the demands of the religious field they entered. One of the key strategies used to incorporate new beliefs was the direct translation of Islamic religious teachings into more familiar Catholic ones. The process does not involve substituting one set of beliefs with another one, but "adjusting similar forms" (Silverman 2005:67). It bears some resemblance to the individual re-appropriation of the new religion as identified by Mossière (2011) in her work on Canadian and French converts. Theological continuity with Christianity, 
along with maintaining some elements of Catholic practices, is an important foundation for the construction of biographical continuity. Although in the converts' narratives, Islam as a way of life is emphasized over explicitly stated beliefs, the latter were referenced in most interviews. Many women emphasized the similarities between Christianity and Islam by pointing to the prophets shared by the two religions, with particular importance given to the figure of Jesus. Zofia, for example, talked about the spiritual significance of retaining a relationship with Jesus after becoming Muslim. As illustrated in the quote below, she ascribed more importance to discovering that she did not have to renounce Jesus (as he is considered an important prophet in Islam), than to learning about the prophet Muhammad, who is considered the most important prophet in Islam:

And the fact that Jesus was not God's son and did not suffer for my sins. I didn't know much about Muhammad, I knew some basics, but this was the most important to me, that I was still with Jesus, still in a relationship with him and I did not denounce him in any way. (Zofia)

Most of our participants highlighted the notion that different religions worship the same God. One woman recounted her joy when she was told that "Allah" is an Arabic word for "God" and, through this discovery, was able to connect her Muslim beliefs with her faith in one God prior to conversion. Direct translation of phenomena encountered in the new religious field into a Catholic framework also concerns the understanding of the religious community. In their discussions on different Muslim groups and mosques functioning in the city, the women we spoke to often used the word "parish" to refer to the community attached to a particular mosque.

The focus on finding similarities is balanced out by recognizing differences. Describing their beliefs, converts focus on a limited number of elements that are thought to be the main differences between Catholicism and Islam, such as the doctrine of the Holy Trinity, God's forgiveness of sins, or the divine nature of Jesus Christ. What is important for our discussion is the fact that Catholic doctrine is used as a framework of reference in the process of making sense of Islamic beliefs. This is consistent with Bourdieu's assertion that the meaning and function of religious symbols and doctrines are shaped by the agent's religious habitus (Rey 2007). However, as the old Catholic and the new Muslim religions are read cross-referentially, the Catholic habitus is also transformed in the process.

\section{Recognizing the Power Relations of the Religious Field through Translation}

The converts come to Islam with previously formed dispositions shaping their relationship with religious leaders and authorities in the new field. As they experience a degree of mismatch between their disposition and Islam, they engage in reflexive effort to make sense of its structure. In the process, they compare the positioning of different actors in Islam and Catholicism and, through translation of different roles, recognize some power relations inherent in the religious field. Questioning religious beliefs and seeking answers to a variety of spiritual questions are the dispositions that many converts retrospectively identify in before their 
conversion. What seems to be the prevailing pattern is that converts were reluctant to search for the answers independently by studying religious sources but instead directed these questions at those who were identified as religious authorities (priests, confessional teachers). Beata, for example, recalled: "[...] I never read the Bible, never. I even didn't ask, because I assumed I wasn't allowed. The Church said this, and the Church luminaries." This disposition to seek external authority is often carried over to the new religious context. Some women mention the imam as a key person in their conversion journey. Unsurprisingly, the imam is perceived by many converts as an important figure imbued with religious authority, and as a much-needed interpreter of Islam:

[Name] is a treasure of Polish Islam, he's a Shi' i imam, he graduated from a [theological] school. [...] he writes such smart stuff, he's so damn smart. He went to school in Iran, he writes theological stuff, wisely, for the people, not just from a Shi'i perspective, but a general Islamic perspective. I'm just saying... we need people like that. (Hanna)

When it comes to Polish Islam. I think we have a problem in Poland. There's nobody like that, except perhaps mufti [name of a high-profile imam in Poland] and his son [name] who are engaging and who I like to listen to. There is nobody who could consolidate this Polish Islam, a real, authentic sheikh. (Krystyna)

While some converts maintain the "undisputed, pre-reflexive, naive, native compliance with the fundamental presuppositions of the field" (Bourdieu 1990b:68) when embracing Islam and continue to endow imams with power and religiously sanctioned authority, others begin to question this position. For the latter group, the translation and recognition of some commonalities and differences between Catholicism and Islam reveal, at least partially, social origins of the power relations immanent in the religious field. In their conscious effort to adjust categories of perception and the principles of classification, they recognize the relations of domination. These women replace the habitual way of deferring to authority figures, particularly in institutionalized religious spaces, with a more horizontal view of religious authority. "The Catholic model of relations between professionals and non-professionals [which] provides the permanent reference" for Bourdieu's understanding of power relations in the religious field loses its relevance (Hervieu-Léger 2000:110). This rejection of religious authorities means that many women readily turn to lay persons (spouses or friends) as knowledgeable sources of guidance in individual queries. For Anna, quoted earlier, the similarity to the hierarchical power relations prevalent in the Catholic Church was a reason to reject Sufism, a particular tradition of Islam which involves a sheikh (a Sufi spiritual master who teaches and guides members of his tariqa, a religious fraternity):

And this Sufism reminds me a bit of the Christian mysticism and Catholicism. There's the sheikh to whom you entrust your life and your decisions and this just brings to mind the Catholic priest. So I don't trust this path within Islam. I prefer the Wahhabis who try to follow the straight path without the human sediment. (Anna) 
Here, Anna likens Sufism to Catholicism, as both rely on intermediaries in the process of connecting to God. Furthermore, she contrasts Sufism and Wahhabism; her perception of and preference for Wahhabism as an Islamic movement "without human sediment" reflects the rejection of "the priest."

A similar shift can be identified in the institutional context of mosque-based religious instruction. While converts are keen to attend lessons and workshops delivered by visiting Islamic scholars, we observed many women participating in the weekend gatherings challenging the authority of these teachers. They were very critical of lectures for women delivered by male scholars, who in converts' view, had a limited knowledge of the Polish socio-cultural context and presented very "detached" perspectives. During our fieldwork, the women attending these lectures decided to organize weekend classes where some of them would take on the role of teachers. This is aligned with observations about female converts' teaching enterprises in the United States (Gray 2019). We observed women giving talks covering topics ranging from Muslim marriage and sexual relations, environmental concerns in Islam, female beauty in Islam, to more theological reflections on trusting in God's plan (Tawkkul), and a female convert-led workshop on Qur'anic recitation. ${ }^{6}$ Notably, some of our respondents experienced silencing and rejection by religious leaders when their initiatives (e.g., organization of mosque-based events) transgressed the institutional religious boundaries.

The authority of religious leaders was also challenged by comparing Catholicism and Islamic guidance with regards to celibacy. For converts, the religiously informed guidance related to relationships, marriage, and family life is more valuable when it is exemplified by the lived experience of religious leaders. Here, the position of an (unmarried) Catholic priest is compared with the position of a married imam:

Half of Islam is really family life, the fulfilment of your faith: Family, wife, so on. There's nothing like that in Christianity, it does not tell you how to treat your wife, how to treat your daughters, how to raise them...and priests do not have family life. Imam will give you advice: do something, do not divorce each other. My husband observed that the divorce rates in Poland were staggering. Why is it like that? Because how can a priest say, respect your family life? He hasn't got a wife, so won't be able to say anything, while an imam has something to say. (Daria)

While some women, like Daria, were prepared to accept an imam's guidance, others preferred to discuss their marital relations with other Muslim women, or

${ }^{5}$ This turn to the idea of pristine Islam among British converts as well as second-and third-generation Muslim youth was examined by Inge (2016). Some scholars argue that upon embracing Wahhabism or Salafism, the lack of cultural capital rooted in "ethnic" Islam becomes less debilitating and can even be transformed into new cultural capital, as the convert is perceived to have no previous ethnic loyalties or cultural bias (Özyürek 2014).

${ }^{6}$ Another example of a convert finding the position of authority and knowledge is an online course on Islamic beliefs aimed at Polish converts with lessons delivered in Polish language and free of charge. The course "O Islamie po polsku" ["On Islam in Polish"] is accessible through the website: https://ayishah-s-school.thinkific.com (accessed on July 11, 2020). 
even organized classes for women, and adopted the roles of teachers and advisors in these matters.

The different positions taken in relation to religious authority apparent in converts' narratives reflect the diversity of attitudes toward clergy among Catholics. The coexistence of these different attitudes might be aligned with the different types of Catholicism described by Inglis (2004), with the "strong" Catholics accepting the position of clergy, "creative" Catholics distancing themselves from religious leaders, and "cultural" and "alienated" Catholics opposing them. Inglis notes, however, that individuals might move between these types. Indeed, in the Polish context, the well-documented lack of enthusiasm towards clergy very often entails a mixture of subordination and antagonistic attitudes (Baniak 2011). By engaging in the translation of power relations between Catholicism and Islam, many converts are able to reflexively manage their position in the new field, to some degree. In that they often act "against an institutionalized culturally oriented and socially controlled understanding of religion" (Shanneik 2011:504) and reject membership in a community with strong dominance of religious leaders.

\section{Translating the Sexual Body from Islam into Catholicism}

The material gathered in our research contains rich phenomenological descriptions of how converts experience their bodies while engaging in new religious practices. The women demonstrate agentic reflection, and the ability to narrate the principles of body conduct and the changes in their bodies (Noble and Watkins 2003). Moreover, through comparing and translating embodied Islamic practices through the lens of Catholic practices, the converts engage in more critical reflexivity and identify at least some aspects of embodied power relations and social positioning.

The sexual body is the subject of intense work in the process of conversion. During our fieldwork, sexuality was a prominent theme of lectures and workshops delivered by visiting male Islamic scholars from Muslim-majority countries and during classes organized and taught by the converts. Women attending the lectures and workshops were keen to learn about Islamic perspectives on sexual practices and aspects of the human body. They engaged in deliberate, intentional learning and appropriation of bodily practices in order to align them with the new religion. The sexual practices were discussed predominantly with reference to religious sources-the Qur'an and the hadith. One of the lectures delivered by a convert started with a strong assertion that sex was good, and God wanted humans to be sexual creatures. The affirmation of sexuality was also evident in the discussion on celibacy - an important element of the Catholic habitus infused with notions of purity and self-discipline. The women compared the status of celibacy in Catholicism and Islam and learned that Islamic texts do not recommend sexual abstinence for anyone. For many, this assertion was very important, as it contradicted the association between leading a pious life devoted to one's religion and rejecting sexual activity, a prominent theme throughout Catholic discourse. 
These observations from the classes are corroborated by our interview data. One participant, Anna, stated that, "Sexuality in Islam is cool [...] Islam is more logical in all this, because if you want to have sex, you can just get married. It is not a complicated issue." She highlighted the clarity and simplicity of Islam, a notion often evoked when comparisons with Catholicism are made. Another woman, Ula, described a change in her bodily dispositions, which she explicitly attributed to her move away from Catholicism to Islam: "I must say that before Islam I was living in strict celibacy. And Islam changed very much this notion that sexuality is sinful. So...I have three children, perhaps this is why."

It has been argued that the power of religious tradition lies mainly in its holistic, overarching scope, legitimized by references to divine will (Berger 1990; Luckman 1967). It seems that converts are very keen to apply religious teachings to their sexual life in toto. Both Catholicism and Islam provide such overarching guidance, but for these women, it might be easier to accept Islamic rules regulating sexual conduct, as illustrated by the following quote:

I really appreciate it, that Islam takes into account sexual needs, physical, biological ones. There are hadith traditions that say that you have actual responsibilities towards your body, just like you have responsibilities towards your family, your spirituality, your mental health...I love Islam for this balance. Living with this religion you do not have to deny yourself anything. (Justyna)

Some of our respondents also discussed polygyny, a practice that is often deemed controversial, complicating as it does the view of Islamic sexual ethics as straightforwardly liberating for women (Ali 2006). Some women in our sample compared living in polygyny to being in a marriage where men are cheating on their wives in order to satisfy their sexual needs. Thus, they translated polygyny into more familiar, common practices and felt that the former was more fair, transparent, and acceptable. Those converts who struggled to wholeheartedly embrace polygyny often manifested a "sacrificial disposition" (Rao 2015:414) in accepting polygyny as a religiously permissible solution to some problems (e.g., infertility).

Many of our participants interpreted Islamic prescriptions on all spheres of life, including sexual practices, as guidelines for moral development, as was highlighted by Zofia:

I was done with this lifestyle and I knew here there were restrictions that would liberate me from it. You know, I won't be able to drink, I won't be able to have sex outside of marriage, I won't be able to dress revealingly, and it will be good for me. It convinced me that my weaknesses would be muzzled, and my positive personality would be liberated. (Zofia)

Here, Zofia exhibits a stance that allows her to reformulate the abandonment of previous dispositions as a spiritual gain. A new disposition shaped through conversion for some women is the shift from a state where they are "disembodied," not paying too much attention to practices that shape and sustain the embodied aspects of their lives, to becoming conscious and reflexive about the ways they treat their bodies. This involves changes in their beauty practices and hygiene regimes related to ritual purity. As a result, they become attentive to and reflexive 
about the treatment of the body. The consequences of that transformation can be profound, as Daria explained:

I started looking after myself more. I attribute this to God. With my first husband, [before conversion], for a very long time I couldn't get pregnant. Doctors said I would not be able to have children, that there was no chance. Since I met my current husband I started praying and asking for a child and it turned out that I was healthy, I got pregnant naturally. [...] This is another sign for me that ditching the substances and the social circle and the party lifestyle and becoming calmer had this effect that my body simply started working that way. (Daria)

The development of more positive attitudes towards the body and sexuality goes hand-in-hand with broader lifestyle changes. For Daria, giving up alcohol, becoming more self-aware of the physical and mental toils of excessive partying, and more attentive to her well-being became a healing process, as she went on to highlight: "...after this change of everything ...I started being healthy not only in my soul, but in my body."

The shaping of new body dispositions is focused on self-kindness, self-care, and self-protection. The implementation of these changes flows from new positive perceptions of their sexual bodies. For some women, these new regimes are natural progressions, though for others, sustaining these new practices of affirmation requires discipline and effort—personal jihad (see Mossiere 2011).

\section{Reflexive Learning and Translating the Embodied Religious Practice of Prayer}

Islamic prayer is identified by converts as one of the most salient elements of the new religion; it is a practice where most converts strive for practical mastery. Praying in Islam is as much physical as mental; it requires movements such as standing up, bending down, and prostrating oneself. Thus, mastering the practice goes beyond learning explicit, consciously accepted rules. Learning Islamic prayer entails developing new disposition, a new bodily bearing-postures, gestures, and ways of speaking (Bourdieu 1991). In the process, new consciousness of the body and its temporal situatedness is shaped, including the development and managing of practices related to the ritual purity (wudu and ghusl).

For many converts, this process requires sustained effort and extensive "body work" (Wacquant 1995:70). The sedimentation (Wacquant 1995) of some of the embodied elements of prayer is a part of the Catholic habitus (Clough 2006). For our participants, however, the calibration of the body and assimilation of a different way of praying, refinement of the technique and naturalization of these skills is, at least to some degree, discursively mediated. The women we spoke to relied on many different resources to achieve embodied mastery. Daria recalled:

How did I learn to pray? The Internet was my treasure trove. I found videos, I learned to pray from YouTube. That's how it was, prayers specifically, step-by-step guides on how to pray, I learned on my own, with no help. (Daria)

${ }^{7}$ For similar discussion on converts in France and Canada, see Mossière (2011). 
For Marta, the desire to learn how to pray became one of the reasons for getting married:

One of the reasons for marriage was to live together, so I could learn such things. During the month when I became a Muslim and lived on my own, I read books about ablutions, prayers, because I had known nothing about that. The books didn't explain how to do it, so I didn't adopt it right away. My first prayer was after the wedding. I was only doing what I could copy from my husband. He was an imam and I copied him, and then I slowly started learning the verses and so on. (Marta)

Engagement with the practices involves not only a reflexive approach to body movements and utterance, for many converts it is also related to conscious location of the particular mode of practice within the diversity of Islam, as stated by Kamila:

There comes a time when every Muslim must choose. It may be unconscious, but they choose. The prayer is the most basic example, because in every of the four schools there are small differences in the positioning, the movements...Some people pray according to how they first learned, by someone, from books, or videos and continue to practice that way unconsciously, unaware that this is from a legal school. (Kamila)

For the Polish converts we interviewed, this process occurs at the very beginning of becoming Muslim. This is consistent with observations made by Winchester (2008), who conceptualizes the embodied religious practices as means of conversion rather than the result of commitment to God. In his view, prayer constitutes and solidifies the commitment. For many converts, the learning and becoming accustomed to the practice of praying five times a day is demanding, as it is often just one of many elements of Islam to which converts must try to learn and adhere. That it was often linked to other ritual practices made the practice of daily prayer even more complex, as expressed by Aneta, who converted to Islam while living in a Muslim-majority country for a year:

In the beginning, after four months, I was really, eh. There was too much of it, the Qur'an and memorizing the prayers, then the prayers themselves which mean something, then the text of the Qur'an, the Hadith, then I, as a European, as Aneta, wanted to get my head around it. I wanted to find myself, at one point I didn't know what to focus on, what I should be doing, there was just too much of it. (Aneta)

For many women, the experience of learning new prayers and the struggles inherent in the process are understood and translated through the lens of the old religion, as illustrated by Zofia's statement:

You know, if I was to compare this to The Apostles' Creed, and it is a quite difficult prayer, it is not always the case that you say [words] and you focus on it. You are just saying what you are saying from memory. And Al-Fatiha this is what we know, everything is there. (Zofia)

${ }^{8}$ The opening of the first chapter of the Qur'an, recited in prayer. 
In a similar way, Ula compares praying in Islam with praying in Catholicism. She highlights the challenge of structuring her time in a way that would accommodate her ritual of praying five times a day:

For me, it is the prayer that's the biggest challenge. Five times a day, at certain times. And that's the most difficult. Perhaps that's a remnant from Hinduism, and Catholicism maybe more, because in Hinduism you are also supposed to meditate and pray at particular times... In Catholicism, your conversation with God is important, and it suits me. You sit and talk to God. I prefer this to military-style. Yes, that's the hardest bit. (Ula)

For Ula, the restructuring of the rhythm of everyday life (the spatiotemporal order) is a challenging task, as she seems to be resisting "the distinction between the more relative time of everyday life and the more absolute and authoritative time of God" (Winchester 2008:1764). Reflecting on the set times of prayer in Islam, she makes explicit reference to dispositions shaped by Catholicism.

Learning the prayer is also inseparable from negotiating the individual's position within the field, whereby the mastery of the practice and adherence constitute symbolic capital for those striving to become pious Muslims, as demonstrated by Thompson (2020) in her study of American progressive mosques. For some women, like Magda, this process is slow and entails some of the "rehearsed spontaneity" of ritual identified by Mahmood (2001:827) in her study of the women's mosque movement in Egypt:

It's still a challenge. I don't always pray five times a day, because I am tired and for example, I do the last prayer, or maghrib together with isha, and in the morning, fajr, and zuhr and asr together, because I feel I could, but it's a struggle, you know? The new Muslim lives with this guilt, that I can't do the five prayers every day. And that's the hardest part, I think. (Magda)

Magda has not been able to combine "pragmatic action" with the "highly codified behavior" (Mahmood 2001:845) of prayer yet, but that she mentions feelings of guilt as a consequence of her perceived failure suggests that she considers such a combination as ideal.

Adherence to praying five times a day also has implications for coverts' positions in other fields. Our respondents live and work in a non-Muslim majority context and their Islamic practices need to be "embedded in the requirements of the field" (Noble and Watkins 2003). Finding an employer in Poland who tolerates multiple Muslim prayer breaks, head coverings, or is willing to provide accommodations during Ramadan is difficult, as many respondents observed (see also Krotofil et al. forthcoming).

\section{Framing Head Covering and Fasting through a Catholic Lens}

In-depth analysis of all the Islamic practices that our respondents adhered to is beyond the scope of a single paper, and hence, in the remaining section, we focus on two categories of embodied practices which, alongside praying, were most strongly emphasized in converts' narratives: head covering and fasting.

The women who participated in our study strive for piety. In the pursuit of it, they submit to many prescriptions, including the adoption of modest clothing. 
The practice of head covering - the hijab-however, is not universal, but is contextual, contingent, and dependent on the individual circumstances of each adherent. Where, for instance, wearing the hijab risks the stigmatization of children, or poses problems with finding a job, respondents are able to take a flexible stance and strategically renegotiate the importance of this particular practice. Many converts who chose to wear the hijab normalize the experience by translating it into the Catholic symbols, similar to Galonnier's (2017) observation of Catholic framing of the hijab in Puerto Rican and Mexican American communities. Polish converts evoke the figure of the Virgin Mary, arguing that she is portrayed wearing the hijab in ubiquitous sacral in Catholic churches.

"We apparently have to cover. But it's totally acceptable that Virgin Mary, as portrayed in church, wears a hijab," stated Iza. Similarly, Beata made connection to the Virgin Mary when critiquing negative reactions to hijab:

I was wondering, had he seen images of Virgin Mary? Because if he goes to church and prays there, etc., and sees someone who is dressed like Mary and insults her, then I do not understand this [faith]. It just makes me wonder, there's something wrong with the Catholic faith. (Beata)

Another category of embodied religious practices ascribed a central role in becoming a good Muslim concerns food and fasting. Fasting during Ramadan, just like praying five times a day, has the potential to restructure the embodied relationship with the everyday world. Although fasting is less performative than some other practices, such as wearing the hijab, it is a "powerful technique for restructuring the body's taken-for granted relationship to the everyday world" (Winchester 2008:1768). Fasting is another practice that can be justifiably reconnected to the Catholic habitus (see Clough 2006), while the specific bodily techniques and visceral sensations are learned in the new religious field. One participant, Daria, made a direct reference to the merging of some element of practices connected to the heritage religion with new religious practices:

And when our [sic] Pope John Paul II changed the rules for the Great Fast..., there used to be customs, traditions, one fast or another, but now you could eat beef. Now the fasting is abolished, to please the people, and that's not right. That's why a lot of people convert to Islam, because it's strict and keeps to the rules, and it's necessary these days. (Daria)

In this fragment, Daria identifies fasting as a Catholic practice, but expresses her disappointment with what she perceives as her heritage religion's inconsistent approach to fasting and striving for the conditions allowing personal cultivation of more momentous or demanding practice. On the other hand, she domesticates the strictness of fasting by decorating her house during the holy month of Ramadan. Daria connected this practice with Christmas celebrations: "I smuggled in some stuff from Christmas, shiny trinkets...I have sparkling crescents for Ramadan. And other decorations."

As with the commitment to praying five times a day, fasting during Ramadan is a practice that is learned over time, introduced by many converts in a tentative manner before the formal conversion. The complex interplay between 
culture, agency, and social structures and the interrelatedness of individual fields are highlighted in converts' narratives by references to the challenges of fasting in social environments where most people do not fast. The women talked about coping with inquisitive looks and questions from non-Muslims in workplaces, being unable to take time off work during Ramadan, and dealing with heat and cold while being unable to drink. These challenges draw attention to the limits of agency. The emphasis on individualization of religion and agency we find in our data does not mean that agency is absolute. Particular contexts have regulatory capacities promoting some choices and inhibiting others. Complex social relationships play a critical role here. For converts with limited social support while in the process of coming to Islam, or little or no contact with other Muslims, the difficulty of fasting was compounded by the seeming impossibility of preparation and celebratory consumption of food. The absence of community networks severely circumscribed Iza's capacity to engage in this embodied aspect of an important and symbolic Islamic practice. She stated: "Like I previously mentioned, I was always on my own and during Ramadan or Eid. I didn't know how to celebrate it. It felt like I was cooking a big breakfast just for myself. Just eat it and be done with it."

While for some converts not being able to celebrate in what they perceived to be the correct manner is a cause for concern, others adopt a flexible approach and consciously fuse Ramadan celebrations with Polish culinary traditions, such as one woman who admitted that sometimes she broke the fast with bigos. ${ }^{9}$ Such weaving together of two ostensibly disparate foodscapes, visible especially in the attempts to "halalize" Polish traditional foods as described by many coverts we interviewed, illustrates the centrality of habitus in the meaning-making related to the new religion. It allows for making connections not only between Catholicism and Islam, but also between the wider culture and performing biographical continuity.

\section{CONCLUSIONS}

In our analysis, we demonstrated the role of religious habitus in the conversion of Polish women of Catholic background to Islam. We argued that for these women, the process of conversion cannot be separated from the hegemonic position of the Catholic Church in Poland. Catholic habitus shared by the majority of Polish converts to Islam is a set of flexible, transposable dispositions that can be deployed, within certain limits, in a variety of social settings and therefore it

${ }^{9} \mathrm{~A}$ traditional Polish dish consisting of pickled cabbage, pork (expressly forbidden in Islam), and wild mushrooms. Polish converts avoid adding pork, thereby creating a halal version of bigos. 
foregrounds their entry into a new religion. It equips them with a set of tools that can be used immediately in the new field.

Converts learn and cultivate new religious knowledge, symbols, and practices, make sense of the institutional dimensions of the new religion, and reconcile multiple roles - past and present—and social identities. The data analyzed in this paper indicate that the scrutiny of past dispositions, emotions, reasoning, and their transformation are inherently social processes. Learning and reflecting take place predominantly in the community of other Polish converts who share the habitus of the heritage religion. This is where gestures are observed and imitated and the meanings of practices and their embodied nuances are negotiated. The collective situatedness of the process facilitates the re-enactment of the shared Catholic habitus and its creative transformation. The social nature of conversion is key to the ability to change the religious habitus that might lie in the specific relationship Polish converts to Islam have with the new religious field. This relationship is "at once familiar and exotic" (Bourdieu 2001:5). It is familiar, as converts enter it through interactions with other converts, with whom they share their upbringing in the Polish socio-cultural environment and the presence of Catholicism in their lives. Yet, it is "exotic," because of the very limited presence of Muslims in Poland.

We argued that habitus is changeable and can be a subject of conscious transformation, through the process of translation of religious beliefs and practices. In the conversion process, Catholic habitus remains pervasive and shapes converts' choices in the process of becoming "good Muslims" and acquiring moral capital in the new religious field. However, as converts advance along their conversion journey, the religious habitus also undergoes a transformation. New practices are learned, and new embodied dispositions are formed and reflected on, while some of the old ones are transformed or abandoned. This process requires effort and discipline and, on the individual level discussed here, it is teleological, its goal being to become a good, pious Muslim.

Being able to connect the old and new religion in a strategic way through translation, and to reflect on the changes within their dispositions, allows converts to remain recognizable to themselves and to maintain biographical continuity. The multidimensional changes in converts' lives, including changes in their embodied selves, do not threaten the continuity of their lives, but are rather, perceived as bringing more cohesion. The Catholic habitus-seen in retrospective as fragmented, or at times inadequate-is transformed into a more holistic set of dispositions penetrating all spheres of life. Transformation is not only enacted and experienced in intuitive, preverbal ways, but is also captured in self-reflection, discursively directed and narrated, as the explicit statements linking the Catholic and Muslim practices presented in this paper indicate. By applying the concept of translation to the analysis of the conversion process, we were able to capture the character of human action as both structured and generative. 
While many elements of the Catholic habitus are retained, and others are reformed, the process of conversion inevitably also brings about the development of new Muslim dispositions. The result is not a linear transformation leading to complete disappearance of the former religion, but a creative fusion of Catholic and Muslim dispositions in the habitus of Polish converts to Islam. In the process, translation and individualization are the key tools. The process of translation implies that the meaning of being Catholic or Muslim is not fixed but can be intermittently renegotiated. Reflexivity is not a constant mode of being in the world, and the temporal fluctuation of reflexivity is apparent also in the context of conversion. It can be argued that for new converts, Islam has a self-conscious quality (Clough 2006), but over time, many practices and ways of being in the world become routinized and automated. In this article, we focused on the early process of learning Islamic practices, reported retrospectively by our respondents. With time, the new habitus starts to operate without continuous introspective insights, and some of its elements become more unconscious. We argue that the debate over whether habitus can be a subject of conscious reflection and modification is based on a false dichotomy. The discussion on which elements of habitus can become accessible to conscious reflection, translated, and transformed seems to be a more productive starting point.

\section{FUNDING}

This work was supported by the National Science Centre, Poland under grant 2017/25/B/HS1/00286.

\section{ACKNOWLEDGMENTS}

We would like to thank Michael C. W. Woolf, Dominika Motak, Cristina L. H. Traina, and Joanna Świecińska who read the first draft and provided helpful comments.

\section{REFERENCES}

Adams, Matthew. 2006. "Hybridizing Habitus and Reflexivity: Towards an Understanding of Contemporary Identity?" Sociology 40: 511-28.

Ali, Kecia. 2006. Sexual Ethics and Islam: Feminist Reflections on Qur'an, Hadith and Jurisprudence. London: Oneworld.

Archer, Margaret S. 2012. The Reflexive Imperative. Cambridge, UK: Cambridge University Press. Asad, Talal. 1986. "The Concept of Cultural Translation in British Social Anthropology."

In Writing Culture: The Poetics and Politics of Ethnography, edited by J. Clifford and G. T. Marcus, 141-64. Berkeley: University of California Press. 
1993. Genealogies of Religion: Discipline and Reasons of Power in Islam and Christianity. Baltimore, MD: John Hopkins Press.

Balogun, Bolaji. 2020. "Race and Racism in Poland: Theorising and Contextualising 'PolishCentrism'.” Sociological Review 68: 1-16.

Balogun, Bolaji, and Remi Joseph-Salisbury. 2021. "Black/White Mixed-Race Experiences of Race and Racism in Poland." Ethnic and Racial Studies 44: 234-251.

Baniak, Józef. 2011. "Kościół Instytucjonalny w Krytycznym Spojrzeniu Dzisiejszych Katolików Polskich (II)." Przegląd Religioznawczy 3: 157-66.

Berger, Peter L. 1990. The Sacred Canopy: Elements of a Sociological Theory of Religion. New York: Anchor Books.

Bourdieu, Pierre. 1977. Outline of a Theory of Practice. Cambridge, UK: Cambridge University Press.

. 1984. Distinction: A Social Critique of the Judgement of Taste. London and New York: Routledge.

—. 1990a. In Other Words: Essays Toward a Reflective Sociology. Stanford, CA: Stanford University Press.

-1990b. The Logic of Practice. Stanford, CA: Stanford University Press. . 1991. Language and Symbolic Power. Cambridge, UK: Polity Press.

- 2001. Masculine Domination. Stanford, CA: Stanford University Press.

Bourdieu, Pierre, and Loïc J. D. Wacquant. 1992. An Invitation to Reflexive Sociology. Cambridge, UK: Polity Press.

Bouzanis, Christoforos, and Stephen Kemp. 2019. "The Two Stories of the Habitus/Structure Relation and the Riddle of Reflexivity: A Meta-Theoretical Reappraisal." Journal for the Theory of Social Behaviour 50: 64-83.

Clough, Paul. 2006. "Social Thought and Commentary: 'Knowledge in Passing': Reflexive Anthropology and Religious Awareness." Anthropological Quarterly 79: 261-83.

Crossley, Nick. 2001. "The Phenomenological Habitus and Its Construction." Theory $\mathcal{E}$ Society 30: 81-120.

Decoteau, Claire L. 2016. "The Reflexive Habitus: Critical Realist and Bourdieusian Social Action." European Journal of Social Theory 19: 303-21.

Galonnier, Juliette. 2015. "The Racialization of Muslims in France and the United States: Some Insights from White Converts to Islam.” Social Compass 62(4): 570-83.

- 2017. "Choosing Faith and Facing Race: Converting to Islam in France and the United States," PhD dissertation, Northwestern University, Evanston, IL and Institut d'Études Politiques, Paris, France.

Gray, Tamara. 2019. "Teaching from the Tent: Muslim Women's Leadership in Digital Religion." PhD dissertation, Education Doctoral Dissertations in Leadership, University of St. Thomas, St Paul, MN: University of St. Thomas.

Hervieu-Léger, Daniele. 2000. Religion as a Chain of Memory. New Brunswick, NJ: Rutgers University Press.

Hilgers, Mathieu. 2009. "Habitus, Freedom, and Reflexivity." Theory and Psychology 19: $728-55$.

Inge, Anabel. 2016. The Making of a Salafi Muslim Woman: Paths to Conversion. New York: Oxford University Press.

Inglis, Tom. 2004. "Catholic Identity, Habitus and Practice in Contemporary Ireland.” Proposed ISSC Working Paper. https:/www.ucd.ie/geary/static/publications/workingpapers/ isscwp2004-13.pdf. Accessed October 14, 2020.

Jenkins, Richard. 1982. "Pierre Bourdieu and the Reproduction of Determinism." Sociology 31: 270-81. 
King, Anthony. 2000. "Thinking with Bourdieu against Bourdieu: A 'Practical' Critique of the Habitus." Sociological Theory 18: 417-33.

Krotofil, Joanna, and Dominika Motak. 2018. "Between Traditionalism, Fundamentalism, and Populism: A Critical Discourse Analysis of the Media Coverage of the migration Crisis in Poland." In Religion in the European Refugee Crisis, edited by U. Schmiedel and G. Smith, 61-85. New York: Palgrave Macmillan.

Krotofil, Joanna, Katarzyna Górak-Sosnowska. Anna Piela and Beata Abdallah-Krzepkowska. Forthcoming. "Being Muslim, Polish, and at Home - Converts to Islam in Poland." Journal of Contemporary Religion.

Luckman, Thomas. 1967. The Invisible Religion: The Problem of Religion in Modern Society. New York: Macmillan.

Mach, Zdzisław. 2007. "The Roman Catholic Church in Poland and the Dynamics of Social Identity in Polish Society." In The Religious Roots of Contemporary European Identity, edited by L. Faltin and M. J. Wright, 117-33. London and New York: Continuum.

Mahmood, Saba. 2001. "Rehearsed Spontaneity and the Conventionality of Ritual: Disciplines of Şalat." American Ethnologist 28: 827-53.

- 2005. Politics of Piety: The Islamic Revival and the Feminist Subject. Princeton, NJ: Princeton University Press.

Mellor, Philip A., and Chris Shilling. 1997. Re-forming the Body. London: Sage.

. 2014. "Re-Conceptualising the Religious Habitus: Reflexivity and Embodied Subjectivity in Global Modernity." Culture and Religion 15: 275-97.

Mishtal, Joanna. 2015. The Politics of Morality: The Church, the State, and Reproductive Rights in Postsocialist Poland. Athens, $\mathrm{OH}$ : Ohio University Press.

Moosavi, Leon. 2015. "The Racialization of Muslim Converts in Britain and Their Experiences of Islamophobia.” Critical Sociology 41: 41-56.

Mossière, Géraldine. 2011. "Devenir Musulmane pour Discipliner le Corps et Transformer L'esprit: L'herméneutique du Sujet Pieux Comme Voie de Restauration du Soi.” Ethnologies 33: $117-42$.

Noble, Greg, and Megan Watkins. 2003. "So, How Did Bourdieu Learn to Play Tennis? Habit, Consciousness and Habituation." Cultural Studies 17: 520-39.

Özyürek, Esra. 2014. Being German, Becoming Muslim: Race, Religion, and Conversion in the New Europe. Princeton, NJ: Princeton University Press.

Piela, Anna. 2020. "Peace versus Conflict-Journalism in Poland: Representation of Islam, Muslims and Refugees by Progressive and Right-Wing Polish Media." In The Routledge Handbook of Religion and Journalism, edited by Kerstin Radde-Antweiler and Xenia Zeiler, 279-295. Abingdon, UK: Routledge.

Račius, Egdūnas. 2018. Muslims in Eastern Europe. Edinburgh, UK: Edinburgh University Press.

Rao, Aliya Hamid. 2015. "Gender and Cultivating the Moral Self in Islam: Muslim Converts in an American Mosque." Sociology of Religion 76: 413-35.

Rey, Terry. 2007. Bourdieu on Religion. Imposing Faith and Legitimacy. London and New York: Routledge.

Roy, Oliver. 2004. Globalised Islam: The Search for a New Ummah. New York: Columbia University Press.

Ryan, Louise, Eleonore Kofman, and Pauline Aaron. 2011. "Insiders and Outsiders: Working with Peer Researchers in Researching Muslim Communities." International Journal of Social Research Methodology 14: 49-60.

Shanneik, Yafa. 2011. "Conversion and Religious Habitus: The Experiences of Irish Women Converts to Islam in the Pre-Celtic Tiger Era." Journal of Muslim Minority Affairs 31: 503-17. 
Silverman, David J. 2005. Faith and Boundaries: Colonists, Christianity, and Community among the Wampanoag Indians of Martha's Vineyard, 1600-1871. Cambridge, UK: Cambridge University Press.

Sweetman, Paul. 2003. "Twenty-First Century Dis-Ease? Habitual Reflexivity or the Reflexive Habitus." The Sociological Review 51: 528-49.

Thompson, Katrina Daly. 2020. "Making Space for Embodied Voices, Diverse Bodies, and Multiple Genders in Nonconformist Friday Prayers: A Queer Feminist Ethnography of Progressive Muslims' Performative Intercorporeality in North American Congregations." American Anthropologist 122: 876-90.

Topidi, Kyriaki. 2019. "Religious Freedom, National Identity and the Polish Catholic Church: Converging Visions of Nation and God." Religions 10: 293.

Trzebiatowska, Marta. 2014. "Beyond Habitus: Researching Gender and Religion Through the Ontology of Social Relations." In Sociological Theory and the Question of Religion, edited by A. MacKinnon and M. Trzebiatowska, 243-61. London and New York: Routledge.

Tyrała, Radosław. 2018. "Living Without God in a Religious Country: Polish Nonbelievers as a Cultural Minority." Social Compass 65: 131-44.

Wacquant, Loïc J. D. 1995. "Pugs at Work: Bodily Capital and Bodily Labour Among Professional Boxers." Body and Society 1: 65-93.

- 2004. "Following Pierre Bourdieu into the Field." Ethnography 5: 387-414.

Weber, Max. 1992. The Protestant Ethic and the Spirit of Capitalism. London and New York: Routledge.

Winchester, Daniel. 2008. "Embodying the Faith: Religious Practice and the Making of a Muslim Moral Habitus." Social Forces 86: 1753-80. 